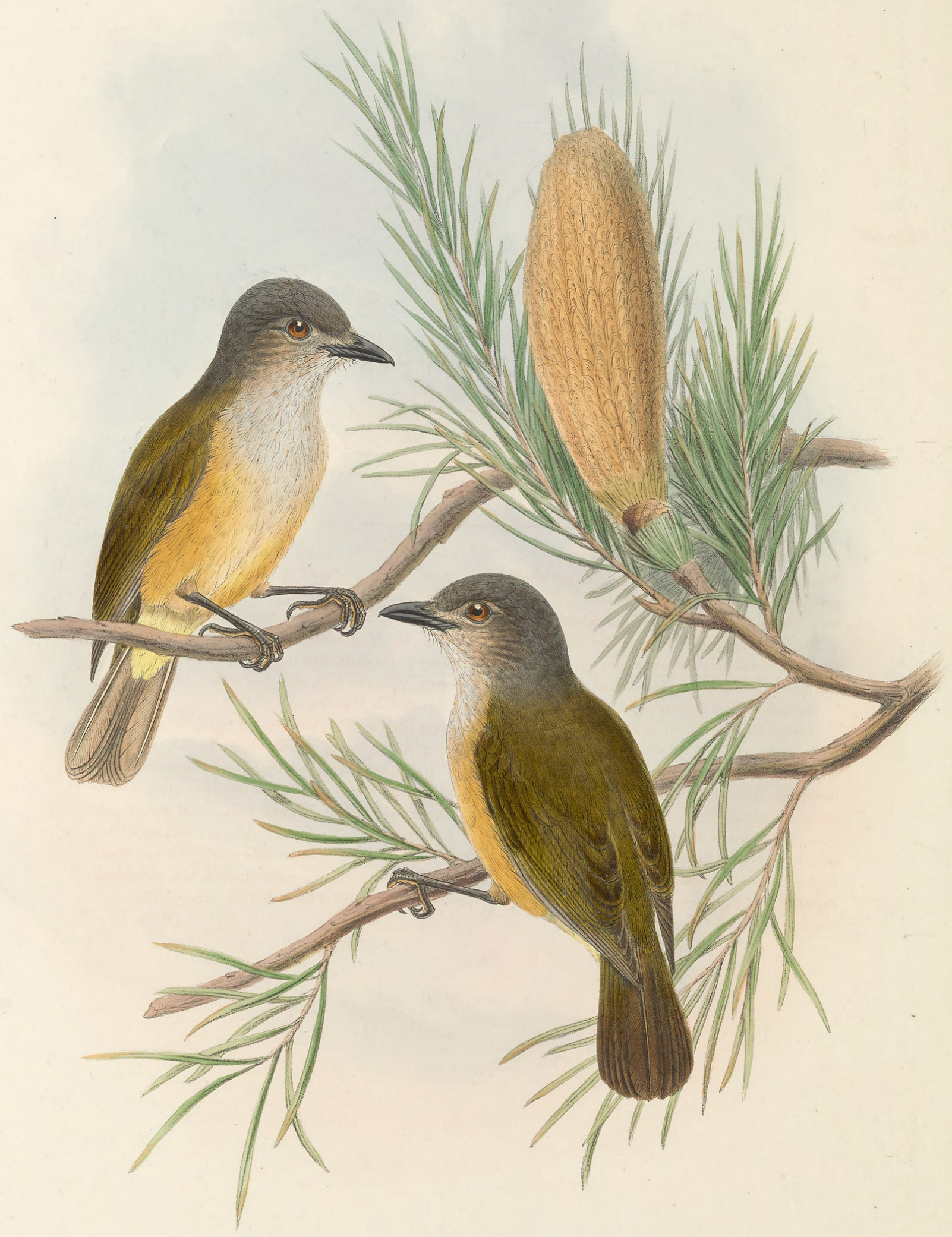




\title{
PACHYCEPHALOPSIS FORTIS.
}

\author{
Grey-throated Thickhead.
}

Pachycephala fortis, Gadow, Cat. Birds in Brit. Mus. vol. viii. p. 369 (1883).

WE have already had the pleasure of figuring two species of Pachycephalopsis in the present work, and we now introduce to our readers a third very interesting species, recently discovered by Mr. A. Goldie during his explorations at the back of the Astrolabe range of mountains in South-eastern New Guinea.

The present species is somewhat allied to $P$. hattamensis, but is strikingly different, being distinguished by the uniform grey throat and breast, the pale yellow under tail-coverts, and the absence of rufous on the wings. It resembles the last-named species, however, in its olive-green back and grey head.

The following is a description of the type specimen in the British Museum :-

Adult. General colour above olive-greenish; wing-coverts like the back, the greater and primary-coverts dusky, externally edged with olive-green, the bastard-wing feathers grey; quills dusky brown, externally olive-green, browner on the primaries, the inner secondaries entirely like the back; tail-feathers dull olivebrown, greener on the edges and barred with dusky under certain lights; head and nape slaty grey, as also the sides of the neck, ear-coverts, and sides of face; lores greyish white; cheeks, throat, and breast pale grey, with narrow dusky shaft-streaks to some of the feathers of the fore neck; abdomen creamy white; sides of body pale brown washed with olive; thighs ashy washed with olive; under tail-coverts yellowish white washed with olive-yellow ; under wing-coverts and axillaries pale olive-yellow ; quills dusky below, ashy along the edge of the inner web. Total length $6 \cdot 6$ inches, culmen $0 \cdot 85$, wing $3 \cdot 65$, tail $2 \cdot 75$, tarsus $1 \cdot 05$. 


\section{$2 \mathrm{BHL}$ Biodiversity Heritage Library}

Gould, John and Sharpe, Richard Bowdler. 1884. "Pachycephalopsis fortis, Grey-throated Thickhead [PI. 24]." The birds of New Guinea and the adjacent Papuan islands : including many new species recently discovered in Australia 3(XVI), -. https://doi.org/10.5962/p.322737.

View This Item Online: https://www.biodiversitylibrary.org/item/229963

DOI: https://doi.org/10.5962/p.322737

Permalink: https://www.biodiversitylibrary.org/partpdf/322737

\section{Holding Institution}

Smithsonian Libraries

\section{Sponsored by}

Biodiversity Heritage Library

\section{Copyright \& Reuse}

Copyright Status: Public domain. The BHL considers that this work is no longer under copyright protection.

This document was created from content at the Biodiversity Heritage Library, the world's largest open access digital library for biodiversity literature and archives. Visit BHL at https://www.biodiversitylibrary.org. 